\title{
Appraisal of Foreign Direct Investment Terrain of Brazil
}

\author{
Manuel Fernandez, Amna Omar Yousif Jasim Aldoukhi \& Alya Mohamed Saeed Ali Obaid Alshamsi \\ School of Business, Skyline University College, PO Box 1797, Sharjah, UAE.
}

\begin{abstract}
Globalization has made worldwide mobility of money easy. Investors prefer to invest in places that offer attractive returns and are relatively less risky. The inflow of FDI gives developing countries access to capital that would otherwise be not available. FDI also provides much needed foreign exchange and thus helps to adjust some of the macroeconomic imbalances in developing countries. Brazil is in the development mode, trying to boost up the growth rates from all corners, but the resources available are limited and very often insufficient, hence the country is competing against others to make the investment climate more investor-friendly and project itself as an investorfriendly destination for the FDI. The main objectives of this study are to find out the status of Brazil as a destination for FDI, the factors that attract FDI into Brazil and the factors that hinder the flow of FDI into Brazil. This study is based on secondary data and covers five years. The study analysis various determinants of FDI like market size, economic growth, infrastructure, political risk, corruption, labor market, raw materials, technological readiness, innovation, financial system, taxation, cost of capital, ease of doing business, and government policies. The study reveals that Brazil's position in the global FDI map is on the decline as most of its rankings by global agencies are declining.
\end{abstract}

Keywords: Foreign direct investment, Investment environment, Transnational Corporations

DOI: $10.7176 / \mathrm{EJBM} / 12-23-05$

Publication date:August $31^{\text {st }} 2020$

\section{Introduction}

World Economy has seen a rapid rise in foreign direct investment (FDI) for more than three and a half decades. FDI has been recognized as the most effective component for economic development and growth, playing a key role for both government and private organizations. FDI enables corporations to quickly acquire new products, technologies, and new markets for their existing products. It is observed that companies investing overseas experience higher growth rates and can diversify their sources of income. A sustainable flow of FDI can generate sustainable development in the host economy. FDI is directly associated with a higher level of production, therefore, it provides the country an opportunity to reduce unemployment and stabilize its political condition.

Global foreign direct investment flows slid by $13 \%$ in 2018, to US $\$ 1.3$ trillion from $\$ 1.5$ trillion the previous year - the third consecutive annual decline, according to UNCTAD's World Investment Report 2019. The inflow of FDI gives developing countries access to capital that would otherwise be not available, as Transnational Corporations (TNCs) often have privileged access to capital from the international banking sector. Similarly, FDI provides much needed foreign exchange and therefore helps to adjust some of the macroeconomic imbalances in developing countries (Fernandez \& Joseph, 2016). Most of the Latin American countries are in the growth mode but the resources available for development with them are limited and insufficient, hence all these nations are competing against each other to make the investment climate better and project itself as the best FDI-friendly destination.

Brazil, officially the Federative Republic of Brazil, is the largest country in both South America and Latin America. At 8.5 million square kilometres and with over 212 million people, Brazil is the world's fifth-largest country by area and the sixth most populous. Brazil is part of the BRICS, along with Russia, India, China, and South Africa. Table 1 gives the data on the inflow of FDI into Brazil during the period 2013 to 2019.

Table 1. Foreign Direct Investment in Brazil: net inflows (US\$ in Billion)

\begin{tabular}{|l|c|c|c|c|c|c|c|}
\hline & 2013 & 2014 & 2015 & 2016 & 2017 & 2018 & 2019 \\
\hline Net inflows & 75.211 & 87.714 & 60.334 & 73.378 & 70.258 & 88.234 & 69.850 \\
\hline Increase & & 12.503 & -27.380 & 13.044 & -3.120 & 17.976 & -18.384 \\
\hline Y-O-Y Growth & $16.62 \%$ & $-31.22 \%$ & $21.62 \%$ & $-4.25 \%$ & $25.59 \%$ & $-20.84 \%$ \\
\hline
\end{tabular}

Source: Compiled from World Bank database

The inflow of FDI during the last five years has decreased by US\$ 17.864 billion, from US\$ 87.714 billion in 2014 to US\$ 69.85 billion in 2019, a decrease of approximately 20\%. The net inflow of FDI into Brazil had a growth of $16.62 \%$ in 2014 , but in 2015 there was a drastic decline of $31.22 \%$, in 2016 there was quite an appreciable recovery of $21.62 \%$ but in 2017 there a decline of $4.25 \%$. In 2018 there a commendable increase of $25.59 \%$, but in 2019 there was a severe decline of $20.84 \%$.

The main objectives of this study are to find out the status of Brazil as a destination for FDI; the factors that attract FDI into Brazil, and the factors that hinder the flow of FDI into Brazil. The findings of the study would help the investors to arrive at a better decision regarding FDI into Brazil, and similarly, help the regulators and 
other stakeholders to formulate appropriate policies and take necessary steps to enhance the FDI attractiveness of Brazil. This paper is organized as follows: Section 2 presents a literature review on FDI. Section 3 states the methodology. Section 4 focusses on analysis and discussions, and Section 5 concludes the paper.

\section{Literature Review}

Foreign direct investment is widely perceived as a powerful development engine for many receiving (host) countries. The study by Osunkwo (2020) attempted to estimate the impact of Foreign Direct Investment on Economic Growth of Nigeria for the period 1980-2018, it was found that FDI has a positive and significant impact on GDP. According to Chaudhuri \& Mukhopadhyay (2014), FDI should be considered as one of the leading growth drivers for a nation as it enables the capital-poor nations to develop physical capital, develop employment opportunities, improve productive capacity and increase the skills of labour by the transfer of advanced technology. Virtually all countries are actively seeking to attract FDI, because of its expected favourable effect on income generation from capital inflows, advanced technology, management skills, and market know-how (Cho, 2003). The motivational factors such as natural resources, market resources, strategic resources, efficiency resources, locational advantages, etc., influenced Multinational Enterprises (MNEs) to perform various activities in the host countries. Initially MNEs search for the customers in host countries and conclude by encompassing productive activities when foreign market confers higher value to the firm (Bhattacheryay, 2018).

Numerous studies have been conducted in different parts of the world and majority of the studies have inspected the effects of determinants of FDI inflow and found that relevant determinants include the size and growth potential of the host market, economic stability, economic growth, infrastructure, geographical location, human capital, interest rate, per capita income, exchange rate, wage rate, quality of institutions, etc. The presentation of the literature review is sequenced in such a manner that the literature relating to market size is presented first, followed by political stability and then literature relating to all other factors.

Market size is expected to have a positive relationship with FDI. Market-oriented FDI aims to set up enterprises to supply goods and services to the local market. The general implication is that host countries with larger market size, faster economic growth, and a higher degree of economic development will provide more and better opportunities for these industries to exploit their ownership advantages and therefore, will attract more market-oriented FDI (OECD, 2000). The study by Resmini (2000), looking into manufacturing FDI, finds that countries in Central and Eastern Europe with larger populations tend to attract more FDI. The studies by Kravis \& Lipesey, (1982), and $\mathrm{Na} \&$ Lightfoot, (2006) revealed that FDI inflow has been largely attracted by the market size and market potential. Xaypanya et al, (2015) investigated the significant factors determining foreign direct in Cambodia, Laos, and Vietnam (ASEAN3) and Indonesia, Malaysia, the Philippines, Thailand, and Singapore (ASEAN5), and found that market size and infrastructure facility are significant factors to attract FDI. Dunning (1973) studied econometric models using a statistical analysis of surveys on the determinants of FDI and found that market forces such as market size, growth, and per capita income in the host country, and cost factors like labour cost and inflation as factors attracting FDI. Casi \& Resmini (2010) inspected the determinants of FDI in the EU region and found that the main determinants are GDP growth rate, labour costs, and market potential. The study by Makki et al, (2004) on the US food processing industry found that market size, per-capita income, and openness significantly affected the US food processing firms' decisions to invest abroad. Thus one may presume that large host countries with a high growth rate and higher per capita income attract higher foreign direct investment due to larger potential demand.

Khachoo \& Khan (2012) conducted a study to examine the determinants of FDI in 32 developing countries from 1982 to 2008 using an econometric model. Their empirical results showed that market size, total reserve, and infrastructure were positively related to FDI inflows.

Political stability and reliability determine the FDI inflows. TNCs prefer stable government so that their investment is protected. Political instability may be in the form of the negative attitude of the government towards TNCs, non-allowance of fund transfer, currency convertibility, war, bureaucracy, and corruption. Political stability can also be measured by the number of changes of democratically elected governments (Gedam, 1996). The study by Root \& Ahmed (1979), and Schneider \& Frey (1985), looking at aggregate investment flows into developing economies found that political instability significantly affects FDI inflows.

Tax policies including corporate and personal tax rates influence inward FDI. Other things being equal a country with lower tax rates should stand a greater chance of attracting FDI projects than a country with higher rates (Chandal, 2003)

According to Neumayer \& Indra (2005), the availability of raw materials provides investors with an added advantage with regards to producing efficiently. The study of Uwubanmwen \& Ajao (2012) shows that trade openness, interest rate, government size, and GDP exerted a positive control on cross-border investments in Nigeria and a negative relationship was found between FDI and exchange rates. According to Milner (2013), the presence of a productive labour force is one of the determinants that influence the scope of FDI in a country.

A glance at the literature on the advantages of inflow of FDI shows that the foremost advantage of FDI is 
increased revenues that can be used for expanding growth opportunities in the investment destination. According to Almutawa \& Maniruzzaman (2014), investments by foreigners refer to additional revenue that supports various economic projects of a country. According to Muysken \& Samia (2006), unemployment rates are reduced as a result of capital injections and job opportunities from foreign-based companies. FDI also increases the competitive advantage of a country by developing financial and business hubs that boost economic growth. Mina (2007) points out that FDI promotes the economic growth of a nation by stimulating various sectors of the economy such as manufacturing and tourism.

In brief, the trend in FDI flows differs by region and country. Although FDI has innumerable effects on the economy of host countries and most countries are trying hard to attract FDI, the inflow of FDI continues to be uneven, with some countries getting the lion's share and others barely getting any.

\section{Methodology}

The main objectives of this study are to find out the status of Brazil as a destination for FDI; the factors that attract FDI into Brazil, and the factors that hinder the flow of FDI into Brazil. The study is solely based on secondary data collected from local, regional and international agencies like Government of Brazil, Central Bank of Brazil, World Economic Forum, International Monetary Fund, Transparency International, World Bank Group, United Nations and various publications of the statistical departments, governments, and the press. The study covers a period of five years from 2014-2015 to 2018-2019. The collected data are tabulated and analyzed using appropriate analytical tools.

\section{Analysis and Discussions}

The Global Competitiveness Report 2019 published by the World Economic Forum assesses the competitiveness landscape of 141 economies, providing insight into the drivers of their productivity and prosperity. These 141 economies account for $99 \%$ of the world's GDP. The competitiveness ranking is based on indicators like Institutions; Infrastructure; ICT adoption; Macroeconomic stability; Health; Skills; Product market; Labor market; Financial system; Market size; Business dynamism; and Innovation capability (Global Competitiveness Report, 2019). The Report series remains the most comprehensive assessment of national competitiveness worldwide. Table 2 presents the year-wise ranking of Brazil by the global competitiveness index for the years 2014 to 2019 .

Table 2. Global Competitiveness Index: Ranking of Brazil - 2014 to 2019

\begin{tabular}{|l|c|c|c|c|c|c|}
\hline Year & 2014 & 2015 & 2016 & 2017 & 2018 & 2019 \\
\hline Global Rank & 57 & 75 & 81 & 80 & 72 & 71 \\
\hline
\end{tabular}

Source: Compiled from Global competitiveness reports from 2014 to 2019

The data in Table 2 shows that the relative ranking of Brazil has declined from rank 57 in the year 2014 to rank 71 in the year 2019, which could be either Brazil is going back in competitiveness or other countries are enhancing their competitiveness at an accelerated pace and leaping forward which is pushing Brazil back in the relative ranking. This calls for an analysis of various determinants of FDI beginning with the market size.

\subsection{Market Size}

Market size, growth in market size, and market efficiency are important determinants of FDI. The market size and the growth prospects of the market of the host country are important pull factors and are positively related to the level of FDI flows (Dunning, 1993; Chandalert, 2000). A huge market size allows the attainment of economies of scale, and transaction costs are lower in countries with higher levels of economic development (Caves, 1971; Zhao \& $\mathrm{Zhu}, 2000)$.

Brazil is the largest and most populous nation in Latin America. The population of Brazil is more than 212 million. Brazil is the ninth-largest economy in the world, with the GDP (PPP) of US\$3,456.357 billion and GDP (PPP) per capita income of US\$ 16,461.794 according to the International Monetary Fund, World Economic Outlook Database (October, 2019). The market size can be measured by the population and the growth of the population of the country. Brazil is the 6th most populous country in the world, with a constant population growth rate. A larger population means a better domestic market that can consume goods and services provided by investors. The growing population brings plenty of opportunities for the investors both domestic and international, which certainly will attract FDI. Table 3 gives the global ranking for Brazil on market size for the period 2014 to 2019 .

Table 3. Market Size: Global Competitiveness Index Ranking of Brazil - 2014 to 2019

\begin{tabular}{|l|c|c|c|c|c|c|}
\hline Year & 2014 & 2015 & 2016 & 2017 & 2018 & 2019 \\
\hline Global Rank & 9 & 7 & 8 & 10 & 10 & 10 \\
\hline
\end{tabular}

Source: Compiled from Global competitiveness reports from 2014 to 2019

Brazil's position for the last three years is at rank 10, they are retaining their supremacy in Latin America 


\subsection{Economic Growth}

Over the past few years, global growth has fallen sharply. Among advanced economies, the weakening has been broad-based, affecting major economies (the United States and especially the euro area) and smaller Asian advanced economies. The slowdown in activity has been even more pronounced across emerging markets and developing economies, including Brazil, China, India, Mexico, and Russia. (World Economic Outlook, October 2019). In least-developed economies, growth remains well below potential and highly volatile. Productivity growth started slowing down well before the financial crisis of 2008. Between 2000 and 2007, total factor productivity (TFP) annual growth averaged just $1 \%$ in advanced economies and $2.8 \%$ in emerging and developing economies. TFP then plummeted during the crisis. Between 2011 and 2016, TFP grew by $0.3 \%$ in advanced economies and $1.3 \%$ in emerging and developing economies (Obstfeld \& Duval, 2018). Corporates do not operate in a vacuum, they are highly influenced and attracted by the environmental factors and economic growth of the economy in which they do business. Corporates in high growth economies can envisage to growth at a higher rate than those in the low growth countries as the environment highly influences the entity (Fernandez, et al, 2020). Table 4 shows the annual percentage growth rate of GDP at market prices based on constant local currency, for Brazil during the period 2014 to 2018 .

Table 4. Economic Growth of Brazil - 2014 to 2018

\begin{tabular}{|l|c|c|c|c|c|c|}
\hline Year & 2014 & 2015 & 2016 & 2017 & 2018 & Average \\
\hline Growth rate & $0.50 \%$ & $-3.55 \%$ & $-3.31 \%$ & $1.06 \%$ & $1.12 \%$ & $-0.84 \%$ \\
\hline Global Rank & 162 & 179 & 182 & 158 & 159 & \\
\hline
\end{tabular}

Source: Compiled from The GlobalEconomy.com, reports 2014 to 2018

The global average growth rate for 2018 was $3.31 \%$. After the 2015-2016 recession, real GDP grew by only $1.06 \%$ in 2017 and $1.12 \%$ in 2018. During the last five years, Brazil was having a negative growth at an annual average rate of $0.84 \%$, which is making the economy unattractive to investors.

\subsection{Infrastructure}

Infrastructure is a major determinant of FDI. Excellent infrastructure plays a major role in the productivity and profitability of Multinational Corporations (MNCs), and thus, their decision about FDI location. Table 5 gives the global ranking of Brazil for the period 2014 to 2019 based on road connectivity, quality of road infrastructure, railroad density, the efficiency of train services, airport connectivity, the efficiency of air transport services, liner shipping connectivity, the efficiency of seaport services, utility infrastructure, electricity access, electricity supply quality, exposure to unsafe drinking water and reliability of water supply.

Table 5. Infrastructure: Global Competitiveness Index Ranking of Brazil - 2014 to 2019

\begin{tabular}{|l|c|c|c|c|c|c|}
\hline Year & 2014 & 2015 & 2016 & 2017 & 2018 & 2019 \\
\hline Global Rank & 76 & 74 & 72 & 73 & 81 & 78 \\
\hline
\end{tabular}

Source: Compiled from Global competitiveness reports from 2014 to 2019

The infrastructure sector is a key driver for the economy and is highly responsible for propelling overall development. Brazil's infrastructural development appears to be unsatisfactory and seems to be stuck at the same level with their relative ranking marginally decreasing from rank 72 in 2016 to rank 78 in 2019. Brazil's quality of infrastructure is lower than in peer countries because of low public investment in infrastructure over the past two decades. Reducing the infrastructure gap will require public investment funds to be spent more effectively, supplemented by mobilization of private capital through concessions (IMF, 2019). For getting a clearer picture a probe is made into the Logistics Performance Index.

4.3.1. Logistics Performance Index

Logistics is the backbone of the trade, and good logistics can reduce trade costs and make countries compete globally. Getting logistics right, means improving infrastructure, skills, customs and regulations, policies, and governance in the right proportion. The Logistics Performance Index (LPI) is reported by the World Bank once in every two years, based on qualitative and quantitative data on six core performance components, namely: The efficiency of customs and border clearance; The quality of trade and transport infrastructure; The ease of arranging competitively priced shipments; The competence and quality of logistics services; The ability to track and trace consignments, and; The frequency with which shipments reach consignees within scheduled or expected delivery times. Table 6 gives the ranking of Brazil from 2014 to 2018. 
Table 6. Logistics Performance Index: Ranking of Brazil - 2014 to 2018

\begin{tabular}{|c|c|c|c|c|c|c|c|}
\hline & LPI & \multicolumn{6}{|c|}{ Parameter-wise Global ranks } \\
\cline { 1 - 5 } Year & $\begin{array}{c}\text { Global } \\
\text { Rank }\end{array}$ & $\begin{array}{c}\text { Custo } \\
\text { ms }\end{array}$ & $\begin{array}{c}\text { Infrastruc } \\
\text { ture }\end{array}$ & $\begin{array}{c}\text { International } \\
\text { shipments }\end{array}$ & $\begin{array}{c}\text { Logistics } \\
\text { competence }\end{array}$ & $\begin{array}{c}\text { Tracking \& } \\
\text { tracing }\end{array}$ & $\begin{array}{c}\text { Timelin } \\
\text { ess }\end{array}$ \\
\hline $\mathbf{2 0 1 4}$ & 65 & 94 & 54 & 81 & 50 & 62 & 61 \\
\hline $\mathbf{2 0 1 6}$ & 55 & 62 & 47 & 72 & 50 & 45 & 66 \\
\hline $\mathbf{2 0 1 8}$ & 56 & 102 & 50 & 61 & 46 & 51 & 51 \\
\hline
\end{tabular}

Source: Logistics Performance Index, 2014 - 2018

Brazil's ranking in the Logistics Performance Index has gradually improved from 65 in 2014 to 56 in 2018. The improvement is noticed in five pillars but the efficiency of customs and border clearance has marginally declined. The nation has to take more serious steps to improve on this to enhance its competitive advantage. The position of Brazil among the emerging markets is at rank 16 according to the Agility Emerging Markets Logistics Index, 2020

\subsection{Productive Labor Market}

A vibrant diversified labor force attracts foreign direct investments. When international investors look for an investment destination, considerations about the skilled nature of the labor force is a matter of priority that determines their scope of success in a country (Brakman \& Garretsen, 2008). Table 7 gives the data for the labor force which comprises people with ages 15 and older who supply labor for the production of goods and services during the period of study. It includes people who are currently employed and people who are unemployed but seeking work as well as first-time job-seekers.

Table 7. Labor Force in Brazil - 2014 to 2019

\begin{tabular}{|l|c|c|c|c|c|c|}
\hline Year & 2014 & 2015 & 2016 & 2017 & 2018 & 2019 \\
\hline Labor Force (million) & 100.02 & 101.68 & 102.59 & 104.34 & 105.37 & 106.33 \\
\hline Global Rank & 5 & 5 & 5 & 5 & 5 & 5 \\
\hline
\end{tabular}

Source: Compiled from The GlobalEconomy.com reports 2014 to 2019

In 2019 the labor force in Brazil was 106.33 million. Throughout the period of study, Brazil had been retaining positions 5, and the demographics of Brazil is quite young. According to Worldometers, the median age in Brazil is 33.5 years. Now let us look at the labor market efficiency, Table 8 gives the ranking for Brazil on labor market efficiency during 2014 to 2019 based on cooperation in labor-employer relations, the flexibility of wage determination, hiring and firing practices, redundancy costs, active labor market policies, workers' rights, ease of hiring foreign labor, internal labor mobility, the effect of taxation on incentives to work, pay and productivity, reliance on professional management, and the ratio of women in the labor force.

Table 8. Labor Market Efficiency: Global Competitiveness Index Ranking of Brazil - 2014 to 2019

\begin{tabular}{|l|c|c|c|c|c|c|}
\hline Year & 2014 & 2015 & 2016 & 2017 & 2018 & 2019 \\
\hline Global Rank & 109 & 122 & 117 & 114 & 114 & 105 \\
\hline
\end{tabular}

Source: Compiled from Global competitiveness reports from 2014 to 2019

An efficient labor market, easy availability of skilled labor, the ready availability of training facilities, and the capacity to attract and retain the right talent from within the country and other parts of the globe are the most important factors that attract international investors. Brazil is ranked 105 out of 141 nations ranked which is not very appreciable, but the positive side is that it has improved from the lower ranks in the preceding years. The country invests more money in education than other peer countries, the University of São Paulo is the second-best university in Latin America, according to recent 2019 QS World University Rankings. Of the top 20 Latin American universities, eight are Brazilian. There is still lots of room for improvement if Brazil wants to boost its FDI attractiveness.

\subsection{Political Risk}

TNCs usually assess political risk before investing in any country. There are many forms of political risks, but the extreme form is the possibility that the host country will take over a subsidiary. However, this form of political risk is an extreme case and not very common in today's global world. The more common forms of political risk include the negative attitude of the host government to TNCs, blockage of fund transfer, currency inconvertibility, war, bureaucracy, and corruption. Credendo Group provides business and economic data for 200 countries and has classified country risk under different indicators like political risk short term, political risk medium/long term, special transactions risk, transfer risk, expropriation risk, and political violence risk; under each of these indicators countries are classified into seven categories: from 1 (low risk) to 7 (high risk); among them, the last three are related to direct investments, and let us probe into that a little bite. 


\subsubsection{Transfer Risk}

The currency inconvertibility and transfer restriction risk refer to the inability to convert and transfer out of the host country any funds related to the investment. The average value for Brazil during the latter period of study is 5 for each year from 2016 to 2019 . Which indicates that currency inconvertibility and transfer restriction risk is high for Brazil.

4.5.2. Expropriation Risk

The risk of expropriation encompasses all discriminatory measures taken by a host government which deprive the investor of its investment without any adequate compensation; and also includes events of the embargo, change of (legal) regime and denial of justice, and the probability of a negative change in attitude towards foreign investments. The average value for Brazil during the period of study is 3 for each year from 2014 to 2019 . Which indicates that expropriation risk is low in Brazil.

4.5.3. Political Violence Risk

Political violence includes all violent act(s) undertaken with a political objective; and includes terrorism (political, religious, and ideological objectives) and political violence damage (damage to material assets as a result of political violence); business interruption as a result of political violence damage. In order to assess the political violence risk, the index looks at the actual levels of internal violence in and external conflict with a country, but also at the conflict potential that arises from (lingering) internal and external tensions, frustration and dissatisfaction. The average value for Brazil during the period of study is 2, which indicates that the political violence risk is very low for Brazil. Table 9 gives the consolidated ranking for the period 2014 to 2019.

Table 9. Country Risk: Credendo Group Index Ranking of Brazil - 2014 to 2019

\begin{tabular}{|l|c|c|c|c|c|c|}
\hline Year & 2014 & 2015 & 2016 & 2017 & 2018 & 2019 \\
\hline Transfer risk & 3 & 3 & 5 & 5 & 5 & 5 \\
\hline Expropriation risk & 3 & 3 & 3 & 3 & 3 & 3 \\
\hline Political violence risk & 2 & 2 & 2 & 2 & 2 & 2 \\
\hline
\end{tabular}

Source: Compiled from Credendo Group index reports 2014 to 2019

The international investors can be sure that they will get a warm welcome in Brazil, their funds may not be blocked, may have easy convertibility, and fewer bureaucracy bottlenecks. Now let us go deeper look into the levels of corruption in Brazil.

4.5.4. Corruption

Corruption distorts competition and investment and hinders free and fair trade. The study by Mauro (1995) found that corruption lowers investment and thereby economic growth. In regard to foreign direct investment, studies have shown that there exist economic consequences of corruption, the study by Smarzynska \& Wei (2001) revealed that foreign investor's choice of entry mode may be affected by the extent of corruption in a host country. Corruption makes dealing with government officials, for example, to obtain local licenses and permits, less transparent and costlier, particularly for foreign investors. In this case, having a local partner lowers the transaction cost, such as the cost of securing local permits. At the same time sharing ownership may lead to technology leakage. Both costs of local permits and losses from technology leakage are positively related to the extent of corruption in a host country.

When corruption level is sufficiently high no investment will take place. Transparency International has published the Corruption Perceptions Index (CPI) since 1995, annually ranking countries by their perceived levels of corruption, as determined by expert assessments and opinion surveys. The CPI generally defines corruption as 'the misuse of public power for private benefit.' Table 10 displays the ranks assigned to Brazil during the last six years.

Table 10. Corruption: Global Ranking of Brazil - 2014 to 2019

\begin{tabular}{|l|c|c|c|c|c|c|}
\hline Year & 2014 & 2015 & 2016 & 2017 & 2018 & 2019 \\
\hline Global Rank & 69 & 76 & 79 & 96 & 105 & 106 \\
\hline
\end{tabular}

Source: Compiled from the Corruption Perceptions Index 2041 to 2019

The ranking by the Corruption Perceptions Index shows that the level of corruption is increasing in Brazil, this will make the country unattractive to international investors.

\subsection{Interest Rates}

High-interest rates tend to slow the growth of an economy and reduce the demand for the TNC's products and thus can negatively impact the flow of FDI. High loan interests translate into cost burden of a company and have been evidenced by the companies that decide to halt operations and move to other regions with low-interest rates. From the perspective of an investor, low interest rates are better as compared to high rates because returns are high when the interest charges are low. Reduction of interest on loans is being introduced by the government of many countries for the purpose of creating an ideal environment for both domestic and international investments. Destinations with such incentives are bound to attract more investors than destinations with high interest rates. 
The lending rate is the bank rate that usually meets the short- and medium-term financing needs of the private sector. This rate is normally differentiated according to the creditworthiness of borrowers and the objectives of financing. Table 11 gives the lending interest rates in Brazil during the period 2014 to 2019

Table 11. Lending Interest Rates in Brazil - 2014 to 2019

\begin{tabular}{|l|c|c|c|c|c|c|}
\hline & 2014 & 2015 & 2016 & 2017 & 2018 & 2019 \\
\hline Interest Rate & $32.01 \%$ & $43.96 \%$ & $52.10 \%$ & $46.92 \%$ & $39.08 \%$ & $37.47 \%$ \\
\hline Global Rank & 3 & 3 & 2 & 2 & 3 & 3 \\
\hline
\end{tabular}

Source: Compiled from TheGlobalEconomy.com reports 2014 to 2019

The global average lending interest rates for 2019 was $10.99 \%$. The lending rate in Brazil very much higher than the global average, though it has started to decrease in the recent past, which is a good sign. But it is not sufficient to attract investors as they will be looking for loans at a lower cost, as the cost of capital impacts the corporate decisions and return on investment measuring parameters.

4.6.1. Financial System

The presence of financial institutions with sufficient liquidity and transparency to grant quick loans at competitive rates is an important determinant. The Brazilian financial system is by far the largest and arguably the most sophisticated in Latin America. Table 12 gives the ranking for Financial System of Brazil 2014 to 2019 based on the availability of domestic credit to the private sector, financing of SMEs, venture capital availability, market capitalization, insurance premium, soundness of banks, non-performing loans as a percentage of loan portfolio value, credit gap and banks' regulatory capital ratio

Table 12. Financial System: Global Competitiveness Index Ranking of Brazil - 2014 to 2019

\begin{tabular}{|l|c|c|c|c|c|c|}
\hline Year & 2014 & 2015 & 2016 & 2017 & 2018 & 2019 \\
\hline Global Rank & 53 & 58 & 93 & 92 & 57 & 55 \\
\hline
\end{tabular}

Source: Compiled from Global competitiveness reports from 2014 to 2019

The rank of Brazil had been marginally declining throughout the period of study, from 53 in 2014 to 55 in 2019 , thus the country has to come out with policies and measures to strengthen the financial system if it wants to attract FDI.

\subsection{Tax Rates and Clarity of Taxation Policies}

Lower tax will give corporates and individuals more after-tax income that could enhance the wealth of the corporates, and individuals could use for buying more goods and services, or for saving. Investors prefer lowertax locations to locate or relocate their businesses. Brazil has a complex tax system, simplifying the tax system would boost private investments.

4.7.1. Corporate Tax

Table 13 gives the corporate tax rates for BRICS Countries and the global average.

Table 13. Corporate Tax Rates (in \%) for BRICS Countries - 2014 to 2019

\begin{tabular}{|l|c|c|c|c|c|c|}
\hline & 2014 & 2015 & 2016 & 2017 & 2018 & 2019 \\
\hline Brazil & 34 & 34 & 34 & 34 & 34 & 34 \\
\hline Russia & 20 & 20 & 20 & 20 & 20 & 20 \\
\hline India & 33.99 & 34.61 & 34.61 & 34.61 & 35 & 30 \\
\hline China & 25 & 25 & 25 & 25 & 25 & 25 \\
\hline South Africa & 28 & 28 & 28 & 28 & 28 & 28 \\
\hline Global average & 23.88 & 23.77 & 23.62 & 24.06 & 24.02 & 23.79 \\
\hline
\end{tabular}

Source: Compiled from KPMG data

The corporate tax rates are quite high in Brazil. During the period of study, the corporate tax rate in Brazil is constant at $34 \%$, which is one of the highest among the BRICS countries and is very much higher than the global average.

4.7.2. Income Tax

Table 14 gives the individual income tax rates for BRICS Countries and the global average. 
Table 14. Income Tax Rates (in \%) for BRICS Countries - 2014 to 2019

\begin{tabular}{|l|c|c|c|c|c|c|}
\hline & 2014 & 2015 & 2016 & 2017 & 2018 & 2019 \\
\hline Brazil & 27.50 & 27.50 & 27.50 & 27.50 & 27.50 & 27.50 \\
\hline Russia & 13 & 13 & 13 & 13 & 13 & 13 \\
\hline India & 33.99 & 33.99 & 35.54 & 35.54 & 35.88 & 35.88 \\
\hline China & 45 & 45 & 45 & 45 & 45 & 45 \\
\hline South Africa & 40 & 40 & 41 & 45 & 45 & 45 \\
\hline Global average & 31.08 & 30.8 & 30.97 & 31.41 & 31.39 & 31.23 \\
\hline
\end{tabular}

Source: Compiled from KPMG data

The individual income tax rates are relatively reasonable in Brazil. All the years during the period of study the individual income tax rate in Brazil is one of the lowest among BRICS countries, it is also lower than the global averages. Lower income tax reduces the cost of running a business because at the time of salary negotiations the prospective employee looks at the after-tax annual pay package offered. The country can rest assured that the lower income tax rates will attract and retain a highly talented and skilled workforce that is needed for the domestic and MNCs operating in the country.

\subsection{Strategic Location}

Brazil is the largest country in South America, and occupies a large area along the eastern coast of South America, sharing land borders with Uruguay to the south; Argentina and Paraguay to the southwest; Bolivia and Peru to the west; Colombia to the northwest; and Venezuela, Guyana, Suriname and France (French overseas region of French Guiana) to the north. It shares a border with every South American country except Ecuador and Chile.

\subsection{Availability / Easiness to Import of Raw Materials}

The availability of raw materials means that international investors can do business in the country without having concerns about the supply of production materials. Brazil is endowed with abundant natural resources and is the largest producer of coffee for the last 150 years. Brazil is one of the largest producers of oranges, coffee, sugar cane, cassava, sisal, soybeans, and papayas. This wide range of these resources that can be used for manufacturing processes has motivated many foreign investors to invest in the country. The import-export policy is quite friendly and liberal, which permits manufacturers to import those raw materials that are not readily available in the country. But, the government will have to still improve the polices to attract more FDI into the country

\subsection{Technology Adoption and Innovation}

Technology is an important consideration made by foreign investors because it determines the scope of operational efficiency. From an investment perspective, the lack of efficient technology systems implies that operations would be slow and costly, and, thus, there will be a need for choosing destinations with a higher level of technology. Table 15 gives the ranking for Brazil on ICT adoption from 2014 to 2019 based on mobile-cellular telephone subscriptions, mobile-broadband subscriptions, fixed broadband internet subscriptions, fiber internet subscriptions, and internet users.

Table 15. ICT Adoption: Global Competitiveness Index Ranking of Brazil - 2014 to 2019

\begin{tabular}{|l|c|c|c|c|c|c|}
\hline Year & 2014 & 2015 & 2016 & 2017 & 2018 & 2019 \\
\hline Global Rank & 58 & 54 & 59 & 55 & 66 & 67 \\
\hline
\end{tabular}

Source: Compiled from Global competitiveness reports from 2014 to 2019

In ICT adoption Brazil seems to be quite appreciable, though its global ranking has slightly declined from rank 58 in 2014 to 67 in 2019. It has plenty of room for improvement, hence it is suggested that the policymakers take more initiatives to encourage faster adoption of ICT. Table 16 gives the ranking for Brazil on innovation friendliness from 2014 to 2019 based on diversity of the workforce, state of cluster development, international coinvention, multi-stakeholder collaboration, scientific publications, patent applications, R\&D expenditures, prominence of research institutions, buyer sophistication and applications made for trademark.

Table 16. Innovation Capacity: Global Competitiveness Index Ranking of Brazil - 2014 to 2019

\begin{tabular}{|l|c|c|c|c|c|c|}
\hline Year & 2014 & 2015 & 2016 & 2017 & 2018 & 2019 \\
\hline Global Rank & 62 & 84 & 100 & 85 & 40 & 40 \\
\hline
\end{tabular}

Source: Compiled from Global competitiveness reports from 2014 to 2019

In innovation friendliness Brazil has made improved quite appreciably from rank 100 in 2016 to rank 40 in the year 2019, policymakers are to be appreciated for this. Now let us look at the ranking of by Global Innovation Index (GII), which ranks on criteria that include institutions, human capital and research, infrastructure, credit, investment, linkages; the creation, absorption, and diffusion of knowledge; and creative outputs. Table 17 gives the ranking of Brazil in the Global Innovation Index from 2014 to 2019. 
Table 17. Global Innovation Index: Brazil's Ranking - 2014 to 2019

\begin{tabular}{|l|c|c|c|c|c|c|}
\hline Year & 2014 & 2015 & 2016 & 2017 & 2018 & 2019 \\
\hline GII & 61 & 70 & 69 & 69 & 64 & 66 \\
\hline Innovation Inputs & 63 & 65 & 58 & 60 & 58 & 60 \\
\hline Innovation Outputs & 64 & 74 & 79 & 80 & 70 & 67 \\
\hline
\end{tabular}

Source: Compiled from the Global Innovation Index 2014 to 2019

Over the last six years, Brazil's ranking has declined from the rank of 61 in 2014 to rank 66 in 2019. Its ranking in innovation inputs has improved marginally from 63 in 2014 to 60 in 2019 . Whereas, the innovation outputs have declined from 64 in the year 2014 to 67 in the year 2019. The above data shows that Brazil requires more investments and more friendly policies to enhance technology adoption and innovations. This is a huge opportunity for both domestic and international investors to invest and reap high returns as the world is embracing technology in a great way.

\subsection{Ease of Doing Business}

The World Bank Group's Doing Business Report ranks economies based on their ease of doing business. A high ease of doing business ranking means the regulatory environment is more conducive to the starting and operation of a local firm. Table 18 gives the ranking for Brazil from 2015 to 2020.

Table 18. Ease of Doing Business: Brazil's Ranking - 2015 - 2020

\begin{tabular}{|l|c|c|c|c|c|c|}
\hline Year & 2015 & 2016 & 2017 & 2018 & 2019 & 2020 \\
\hline Global Rank & 120 & 116 & 123 & 125 & 109 & 124 \\
\hline
\end{tabular}

Source: Compiled from the Doing Business Report 2015 to 2020

The high degree of corruption coupled with a cumbersome tax and regulatory system has been pushing down the ranking of the country in the Ease of Doing Business rankings from rank 120 in 2015 to rank 124 in 2020

\section{Conclusion}

The review of various factors shows that the attractiveness of Brazil as an FDI destination is deteriorating. A number of global business indexes and global ranking agencies have acknowledged this by assigning lower ranks to Brazil against most of the determinants of FDI. The parameters making Brazil an unattractive destination are the low economic growth, low-quality infrastructure, inefficient customs, and border clearance, relatively low labour market efficiency despite having few of the top Latin American universities, high currency inconvertibility and transfer restriction risks, a high degree of corruption, high lending rate, high corporate tax rates and declining ease of doing business. On the other hand, the factors that contribute in making it attractive are the large market, large young labour force, low political risk, the largest and most sophisticated financial system in Latin America, reasonable individual income tax rates, good location as it shares border with most of the South American countries, appreciable ICT adoption and improving innovation friendliness. Hence, the investors may factor in the compounding effect of all these factors, both positive and negative, while making their investment decisions.

Limitations of this study are that the impacts of current Novel Coronavirus COVID-19 are not factored into the study, as it is still an ongoing pandemic, hence the investors are requested to factor in that while making the investment decisions.

\section{References}

Agility Emerging Markets Logistics Index. (2020). Available: https://www.agility.com/insights/emergingmarkets-logistics-index/rankings/ (June 20, 2020)

Almutawa, Ahmed M, \& A F. M. Maniruzzaman. (2014). The UAE's Pilgrimage to International Arbitration Stardom: A Critical Appraisal of Dubai as a Centre of Dispute Resolution Aspiring to Be a Middle East Business Hub. Journal of World Investment and Trade, 15: 193-244

Bhattacheryay, S. (2018). Foreign Direct Investment in India Opportunities and Challenges. International Journal of Asian Business and Information Management (IJABIM), 9(4), 1-20

Brakman, Steven, \& Harry Garretsen. (2008). Foreign Direct Investment and the Multinational Enterprise. Cambridge, MA: MIT Press.

Business and economic data for 200 countries. Available: https://www.theglobaleconomy.com/download-data.php. (April 18, 2020)

Casi, L., \& Resmini, L. (2010). Evidence on the determinants of foreign direct investment: the case of EU regions. Eastern Journal of European Studies, 1(2), 93-118

Caves, Richard. E. (1971). International Corporations: The Industrial Economics of Foreign Investment. Economica, 35(141), 1-27

Central Bank of Brazil Available: https://www.bcb.gov.br/en

Chandalert, A. (2000). The Determinants of U.S. Direct Investment in Thailand: A Survey on Managerial 
Perspectives. Multinational Business Review, 8(2), 82-88

Chaudhuri, S., \& Mukhopadhyay, U. (2014). Role of FDI in Developing Countries: Basic Concepts and Facts. In Foreign Direct Investment in Developing Countries (pp. 1-17). Springer, New Delhi

Cho JW. (2003). Foreign direct investment: determinants, trends in flows and promotion policies. Investment promotion and enterprise development bulletin for Asia and Pacific, Economic and Social Commission for Asia and Pacific, Thailand, 99-102

Doing Business Global Ranking (2020). Available: http://www.doingbusiness.org/rankings (June 5, 2020)

Dunning, J. H. (1973). The determinants of international production. Oxford Economic Papers, 289-336

Fernandez, M. \& Joseph, R. (2016). UAE the Attractive FDI Destination in the Middle East. International Research Journal of Finance and Economics, (153)

Fernandez, M., Shubaisi, A. M., \& Joseph, R. (2020). Examination of Potentialities of Vietnam as FDI Destination. Journal of Economics and Business, 3(3), 980-994

Gedam, R. (1996). Determinants of FDI and India's experience. (2nd ed.). New Delhi: Deep and Deep Publication.

Global Competitiveness Report (2019). Available: https:/www.weforum.org/reports/how-to-end-a-decade-oflost-productivity-growth (April 12, 2020)

Global Innovation Index (2019). Available: https://www.globalinnovationindex.org/content/page/data-analysis/ (March 14, 2020)

IMF (2019). Available: https:/www.imf.org/en/News/Articles/2019/07/25/NA072519-Six-Charts-on-BoostingGrowth-in-Brazil

Khachoo, A. Q., \& Khan, M. I. (2012). Determinants of FDI inflows to developing countries: a panel data analysis.

KPMG data: Available: https://home.kpmg/xx/en/home/services/tax/tax-tools-and-resources/tax-ratesonline/corporate-tax-rates-table.html (April 14, 2020)

KPMG data: Available: https:/home.kpmg/xx/en/home/services/tax/tax-tools-and-resources/tax-ratesonline/individual-income-tax-rates-table.html (April 14, 2020)

Kravis, I. \& Lipesey, R. (1982). The location of overseas production and production for export by US Multinational firms. Journal of International Economics, 12(3), 201-23

Logistics Performance Index. (2018). Available: http://lpi.worldbank.org/international/global (January 15, 2020)

Makki, S.S., Somwaru, A. \& Bolling, C. (2004). Determinants of Foreign Direct Investment in the food- processing industry: A comparative Analysis of Developed and Developing Economies. Journal of Food Distribution Research, 35(3), 60-7

Mauro, Paolo. (1995). Corruption and Growth. Quarterly Journal of Economics, 110, 681-712.

Milner, Helen V. (2013). The Regime for International Investment: Foreign Direct Investment, Bilateral Investment Treaties, and Trade Agreements.

Mina, W. (2007). The Location Determinants of FDI in the GCC Countries. Journal of Multinational Financial Management, 17(4), 336-348

Muysken, Joan, \& Samia Nour. (2006). Deficiencies in Education and Poor Prospects for Economic Growth in the Gulf Countries: the Case of the UAE. The Journal of Development Studies, 42.6 (2006), 957-980

Na, L., Lightfoot, W. S. (2006). Determinants of foreign direct investment at the regional level in China. Journal of Technology Management in China, 1(3), 262-78

Neumayer, Eric, \& Indra, De Soysa, I. (2005). Trade openness, foreign direct investment and child labour. World Development, 33(1), 43-63

Obstfeld, Maurice \& Romain, Duval. (2018). Tight monetary policy is not the answer to weak productivity growth. Available: https://voxeu.org/article/tight-monetary-policy-not-answer-weak-productivity-growth (April 10, 2020)

OECD. (2000). Main determinants of FDI and its impact of foreign direct investment on China's economy. working papers on international investment no. 4, prepared for OECD cooperation programme

Osunkwo, F. O. (2020). Foreign Direct Investment and Economic Growth of Nigeria (1980-2018). Journal of Economics and Business, 3(1)

Resmini, L. (2000). The Determinants of Foreign Direct Investment in the CEECs. Economics of Transition, vol. 8 (3), 665-89

Root, Franklin \& Ahmed. (1979). Empirical Determinants of Manufacturing Direct Foreign Investment in Developing Countries. Economic Development and Cultural Change, 27(4), 751-767

Schneider, Friedrich \& Bruno S. Frey. (1985). Economic and Political Determinants of Foreign Direct Investment. World Development, 13(2), 161-175

Smarzynska, B. K., \& Wei, S. J. (2001). Corruption and composition of foreign direct investment: firm-level evidence. World Bank Working Paper.

Transparency International, Corruption Perceptions Index. Available: http://www.transparency.org (March 27, 2020)

Uwubanmwen, A. E. \& Ajao, M. G. (2012). The Determinants of foreign direct investment in Nigeria. 
International Journal of Business and Management, 7(24), 67-77

World Bank database. Available: https://data.worldbank.org (May 11, 2020)

World

Economic

Outlook.

(October

2019).

Available:

https:/www.imf.org/external/pubs/ft/weo/2019/02/weodata/index.aspx (May 12, 2020)

World Investment Report. (2019). Available: https://unctad.org/en/PublicationsLibrary/wir2019 en.pdf (June 15, 2020)

Worldometer. Available: www.Worldometers.info (June 20, 2020)

Xaypanya, P., Rangkakulnuwat, P., \& Paweenawat, S. W. (2015). The determinants of foreign direct investment in ASEAN. International Journal of Social Economics, 42(3), 239-250.

Zhao, H. \& Zhu, G. (2000). Location factors and country-of-origin differences: An empirical analysis of FDI in China. Multinational Business Review, 8(1), 60-73. 